\title{
Groundwater Quality Assesment of Some Boreholes from Odo- Oro Ekiti, Southwestern Nigeria
}

\author{
Sunday Olabisi Daramola \\ Department of Geography, College of Education Ikere Ekiti, Ekiti State Nigeria
}

\begin{abstract}
In the present study, physical, chemical and bacteriological characteristics of borehole water samples from Odo-oro Ekiti were studied. The result of the physical tests revealed that the water is colourless, odourless and tasteless, while the result of the chemical tests revealed that the $\mathrm{pH}$ ranges from 4.8-6.8, indicating that the water samples are slightly acidic, temperature ranges from $26^{\circ} \mathrm{c}-29^{\circ} \mathrm{C}$, total hardness ranges from $(5-20) \mathrm{mg} / \mathrm{L}$ and total dissolved solids ranges from $10.5-20.3(\mathrm{mg} / \mathrm{l})$. The analyzed cations and anions in the samples showed that calcium ranges from $(1.2-8.1) \mathrm{mg} / \mathrm{l}$, manganese $(0.01) \mathrm{mg} / \mathrm{l}$, chloride $3.2-8 \mathrm{mg} / \mathrm{l}$, silica 1 $1.2 \mathrm{mg} / \mathrm{l}$, iron 0.01-0.24mg/l, nitrate $0.5-2.2 \mathrm{mg} / \mathrm{l}$, zinc 0.16-0.62 $\mathrm{mg} / \mathrm{l}$, carbonate $0.1-0.9 \mathrm{mg} / \mathrm{l}$, sulphate 0.1$3.2 \mathrm{mg} / \mathrm{l}$, phosphate $0-1.2 \mathrm{mg} / \mathrm{l}$.

The determined physical and chemical parameters reveal that the studied water samples have chemical qualities which render them suitable as drinking water as the determined parameters conforms to the WHO specifications for drinking water and also fell within the fresh water class of the USGS classification of water based on dissolved solids. The high bacteria count is beyond the limit of the World Health Organisation bacteriological standard for drinking water hence, unacceptable and not recommended as potable water unless special treatments and designs are adopted.
\end{abstract}

Keywords: bacteriological; borehole; groundwater; Odo-Oro; Ekiti

\section{Introduction}

Groundwater, surface waters, rain-water and springs are the main sources of water available to the rural dwellers in Nigeria. In the last few decades, there has been a tremendous increase in the demand for fresh water due to rapid growth of population and the accelerated pace of industrialization. The qualities of these water bodies vary widely depending on location and environmental factors. Among the factors determining the qualities of natural waters, ground waters in particular, are the chemical composition of the rocks with which they interact; soil formations and the length of time that the water body has been trapped underground [1].

Groundwater is used for domestic, industrial, water supply and irrigation all over the world. Human health is threatened by unsanitary conditions through open drains carrying and disposing wastewater into natural water bodies. Rapid urbanization, especially in developing countries like Nigeria, has affected the availability and quality of groundwater due to its overexploitation and improper waste disposal, especially in urban areas. According to [2], about $80 \%$ of all the diseases in human beings are caused by water. Once the groundwater is contaminated, its quality cannot be restored back easily and to device ways and means to protect it.

The sources of water for any specific purpose are not as important as the suitability of the water for the desired purpose. With increasing human population, industrialization, urbanization and the consequent increase in demand for water for both domestic and industrial uses, the attendant increase in the implication of polluted water on man and the environment have been severally studied ([3]; [4]).

To communicate information on the quality of water to the concerned citizens and policy makers, analysis of water is utmost important. It thus, becomes an important factor for the assessment and management of groundwater.

Groundwater is important for the existence of the human society as it is a liberal part of the environment; hence it cannot be looked at in isolation especially where high degree of dependence is upon ground water for drinking purpose in Odo-Oro Ekiti and its environment. This research work attempts to investigate the physical, chemical and bacteriological properties of water from boreholes around Odo-Oro metropolis based on these parameters determined; assess its suitability for human consumption

\section{Study Area}

The study area (figure 1) is located within the southwestern part of Nigeria. Geographically, it is situated between $07^{\circ} 31^{\prime} \mathrm{N}$ and $07^{\circ} 47^{\prime}$ and longitudes $005^{\circ} 13^{\prime} 07^{\prime} \mathrm{E}$ and $\mathrm{E} 05^{\circ} 14^{\prime} \mathrm{E}$. Accessibility to the bore holes is aided by road networks which include main roads and footpaths. The study area is underlain by rocks of the basement complex as shown by the geological map of the study area (figure 2). The area consists mainly of migmatites, granite-gneiss, porphyritic granite and charnokitic rocks. Migmatites and granite-gneisses dominate 
the study area, although the migmatites forms a larger part of the study area. Migmatites usually occur as low lying outcrops although around the study area they occur as inselbergs and range of hills [5].

\section{Materials And Methods \\ Sampling Procedures and Laboratory Analysis}

Fieldwork and laboratory studies were undertaken to achieve the aim of the project. Water samples were randomly collected from boreholes within the study area, the water samples were collected early in the morning in order to ensure that mineral matters have settled down. The samples were stored in well drained clean polythene bottles already rinsed out with the same water sample in each case. The samples collected were taken to the laboratory for physic-chemical and bacteriological analysis. The methods used include; titrimetry, colorimetry and gravimetry. Pour plate method was used for enumeration of total bacteria count and most probable number technique [6] was used for estimation of coliforms in the water samples.

\section{Results And Discussion}

The results of the physicochemical analysis of the water samples studied are presented in table 1 . Discussions are done here of the major constituents with major emphasis on their concentration levels in relation to the [2] permissible limits.

All the water samples are clear in colour with Hazen units of 5 , they have no taste and odour with respect to human senses. The temperature ranged from $26^{\circ} \mathrm{C}$ to $29^{\circ} \mathrm{C}$, however, the [2] sets no limits for temperature as regards the suitability of water for drinking. The total dissolved solid reflects the level of minerals (such as bicarbonates, chlorides, sulphate, phosphate, silica, calcium, magnesium, sodium and potassium) that are present in water in dissolved form. The TDS values for the water samples ranged from 10.2$23 \mathrm{mg} / \mathrm{l}$. This range of TDS is still within the World Health Organisation's maximum permissible limit of $1500 \mathrm{mg} / 1$ (Table 2) and also fell within the fresh water class of the USGS classification of water based on dissolved solids. However, the values still conform with the [2] maximum permissible level of 8.5 for potable water. The $\mathrm{pH}$ values obtained here are comparable to other localities in the Nigerian basement complex ([7]and[8]).The $\mathrm{pH}$ values of the rest samples are slightly low (4.8-6.4), slightly acidic and this may cause severe corrosion of the borehole casing and metals in the distribution system.

The results of the turbidity carried out on the water samples fell within the highest desirable limit of the specification of the world health organization for drinking water. The studied samples recorded a value of 3.24.4NTU, hence less turbid. The alkalinity of the water samples ranges between 70 and $110 \mathrm{mg} / 1$ which fall below the World Health Organisation's highest permissible limit. The total hardness of the water samples ranged between $5-20 \mathrm{mg} / \mathrm{l}$ and this complies with the $100 \mathrm{mg} / \mathrm{l}$ highest desirable limit and $500 \mathrm{mg} / \mathrm{l}$ maximum permissible value stipulated by the World Health Organization. Table 3 shows [9] classification of water. The studied water samples falls within $5-20 \mathrm{mg} / \mathrm{l}$, hence it can be adjudged soft. The value of nitrate range from 0 $2.2 \mathrm{mg} / 1$ which still fall within the permissible limit of the World Health Organization. The chloride range between 3.2 and $8.0 \mathrm{mg} / 1$ which falls below the maximum permissible limit of World Health Organization. The range of iron concentration in the tested samples is $(0.08-0.24)$ which is also below the maximum desirable limit of the World Health Organization. High concentration of iron could cause staining of laundry and an undesirable taste in beverages. [10] has noted that groundwater from basement areas have total iron contents of less than $1 \mathrm{mg} / 1$ and rarely exceeding $2 \mathrm{mg} / 1$.

The sulphate concentration range from $0.15-3.20$, the [2] maximum permissible limit is $200 \mathrm{mg} / 1$. [11] observed that a sulphate concentration of more than $250 \mathrm{mg} / 1$ is objectionable for some industries while water containing about $500 \mathrm{mg} / 1$ sulphate tastes bitter. Manganese, like iron is very significant in assessing potability of water as even minute amounts of the element in water are objectionable. Manganese concentration of $0.01 \mathrm{mg} / 1$ was obtained in the study area. All the water samples had their Mangenese levels conforming to the [2] maximum permissible level of $0.5 \mathrm{mg} / 1$. Water with higher concentration is likely to have unpleasant taste.

The total bacterial counts for the analysed water samples from the study area range between $6 \mathrm{Cfu} / 100 \mathrm{ml}$ $35 \mathrm{Cfu} / 100 \mathrm{ml}$ (Table 1 ). This shows a relatively high load of bacteria in the water as no sample should contain more than 3 coliform per $100 \mathrm{ml}$ as stipulated by World Health Organisation.

All the water samples have values of E-Coli greater than zero which is the acceptable value, as World Health Organisation states that no sample should contain E-Coli in 100ml. Coliform organisms should not be detectable in $100 \mathrm{ml}$ water sample.

However, the quality of water is strictly based on some physical, chemical and bacteriological parameters. Some of these parameters are inherent in surface water and their sources are mainly from precipitation, leaching of soil particles during infiltration, decay of organic matter, salt water intrusion, exchange of ions with surrounding rocks and human activities etc. Continuous occurrence of these processes lead to the increase in concentration and values of the parameters which in turn influence water quality. 
TABLE 1: DATA FROM THE CHEMICAL AND BIOLOGICAL ANALYSIS

\begin{tabular}{|c|c|c|c|c|c|c|c|c|c|c|}
\hline Parameters & BH1 & BH2 & BH3 & $\mathrm{BH} 4$ & BH5 & BH6 & BH7 & BH8 & BH9 & $\mathrm{BH} 10$ \\
\hline $\mathrm{pH}$ & 4.80 & 5.20 & 6.20 & 5.70 & 4.90 & 5.40 & 5.50 & 5.40 & 6.40 & 6.80 \\
\hline Turbidity(Ntu) & 4.00 & 4.00 & 3.20 & 4.20 & 4.10 & 4.20 & 4.40 & 3.30 & 3.80 & 4.40 \\
\hline Dissolve $02(\mathrm{mg} / \mathrm{l})$ & 6.20 & 5.00 & 5.20 & 6.00 & 6.00 & 5.00 & 6.00 & 6.00 & 5.00 & 5.00 \\
\hline Total alkalinity $(\mathrm{mg} / \mathrm{l})$ & 110.00 & 100.00 & 75.00 & 110.00 & 110.00 & 75.00 & 100.00 & 80.00 & 70.00 & 80.00 \\
\hline Calcium(mg/l) & 4.20 & 1.20 & 2.60 & 2.40 & 2.80 & 8.10 & 1.20 & 2.80 & 1.50 & 2.00 \\
\hline Chloride(mg/l) & 3.80 & 3.20 & 4.10 & 5.50 & 6.00 & 4.50 & 4.90 & 4.20 & 8.00 & 6.50 \\
\hline Silica(mg/l) & 1.00 & 1.00 & 1.20 & 1.00 & 1.20 & 1.20 & 1.20 & 1.00 & 1.00 & 1.20 \\
\hline Iron(mg/l) & 0.01 & 0.24 & 0.15 & 0.10 & 0.10 & 0.17 & 0.10 & 0.08 & 0.10 & 0.08 \\
\hline Manganese(mg/l) & 0.01 & 0.01 & 0.01 & 0.01 & 0.01 & 0.01 & 0.01 & 0.01 & 0.01 & 0.01 \\
\hline Total Hardness $(\mathrm{mg} / \mathrm{l})$ & 20.00 & 12.00 & 30.00 & 10.00 & 5.00 & 17.00 & 12.00 & 10.00 & 15.00 & 20.00 \\
\hline Nitrate(mg/l) & 2.20 & 0.50 & 0.10 & 0.10 & 0.10 & 1.60 & 0.00 & 0.00 & 0.10 & 0.10 \\
\hline Total Dissolve (mg/l) & 23.00 & 13.80 & 13.40 & 12.90 & 10.50 & 10.80 & 10.20 & 12.20 & 10.50 & 12.20 \\
\hline Zinc(mg/l) & 0.50 & 0.50 & 0.62 & 0.18 & 0.16 & 0.45 & 0.12 & 0.14 & 0.17 & 0.15 \\
\hline Carbonate(mg/l) & 0.90 & 0.60 & 0.70 & 0.70 & 0.40 & 0.10 & 0.50 & 0.10 & 0.30 & 0.10 \\
\hline Sulphate(mg/l) & 3.20 & 0.15 & 0.60 & 0.20 & 0.10 & 0.50 & 0.10 & 0.10 & 0.25 & 0.20 \\
\hline Phosphate(mg/l) & 0.00 & 1.20 & 0.20 & 0.00 & 0.30 & 0.00 & 0.00 & 0.00 & 0.00 & 0.10 \\
\hline TBC(cfu/100ml) & 6 & 30 & 20 & 35 & 14 & 8 & 18 & 8 & 18 & 14 \\
\hline Coliform count & 3.00 & 4.00 & 4.00 & 3.00 & 4.00 & 3.00 & 3.00 & 2.00 & 2.00 & 3.00 \\
\hline
\end{tabular}

TABLE 2: COMPARISON BETWEEN VALUES OF PARAMETERS FROM THE STUDY AREAS AND THE WHO STANDARD

\begin{tabular}{|c|c|c|c|}
\hline CHARACTERISTICS & HIGHEST DESIRABLE & VALUES FOR THE STUDIED SAMPLES \\
\hline colour & 5 & 50 & 5 \\
\hline turbidity (NTU) & 5 & 25 & $3.2-4.4$ \\
\hline pH & $7-8.5$ & $6.5-9.2$ & $4.8-6.8$ \\
\hline chloride (mg/l) & 200 & 600 & $3.2-8$ \\
\hline manganese(mg/l) & 0.05 & 0.5 & 0.01 \\
\hline iron(mg/l) & 0.1 & 1 & $0.08-0.24$ \\
\hline nitrate(mg/l) & 45 & 50 & $0-2.2$ \\
\hline total hardness & 100 & 500 & May-30 \\
\hline CaCO3(mg/l) & 100 & 500 & $0.1-0.9$ \\
\hline sulphate (mg/l) & 200 & 400 & $0.10-3.2$ \\
\hline zinc(mg/l) & 5 & 15 & $0.12-0.62$ \\
\hline calcium(mg/l) & 75 & 200 & $1.2-4.2$ \\
\hline TDS & 500 & 1500 & $10.2-23$ \\
\hline
\end{tabular}

TABLE 4.3: WATER CLASSIFICATION ACCORDING TO [9]

\begin{tabular}{|l|l|}
\hline hardness & Range $(\mathrm{mg} / \mathrm{l})$ \\
\hline Soft & $0-60$ \\
\hline Moderate & $61-120$ \\
\hline Hard & $121-180$ \\
\hline Very hard & $>180$ \\
\hline
\end{tabular}




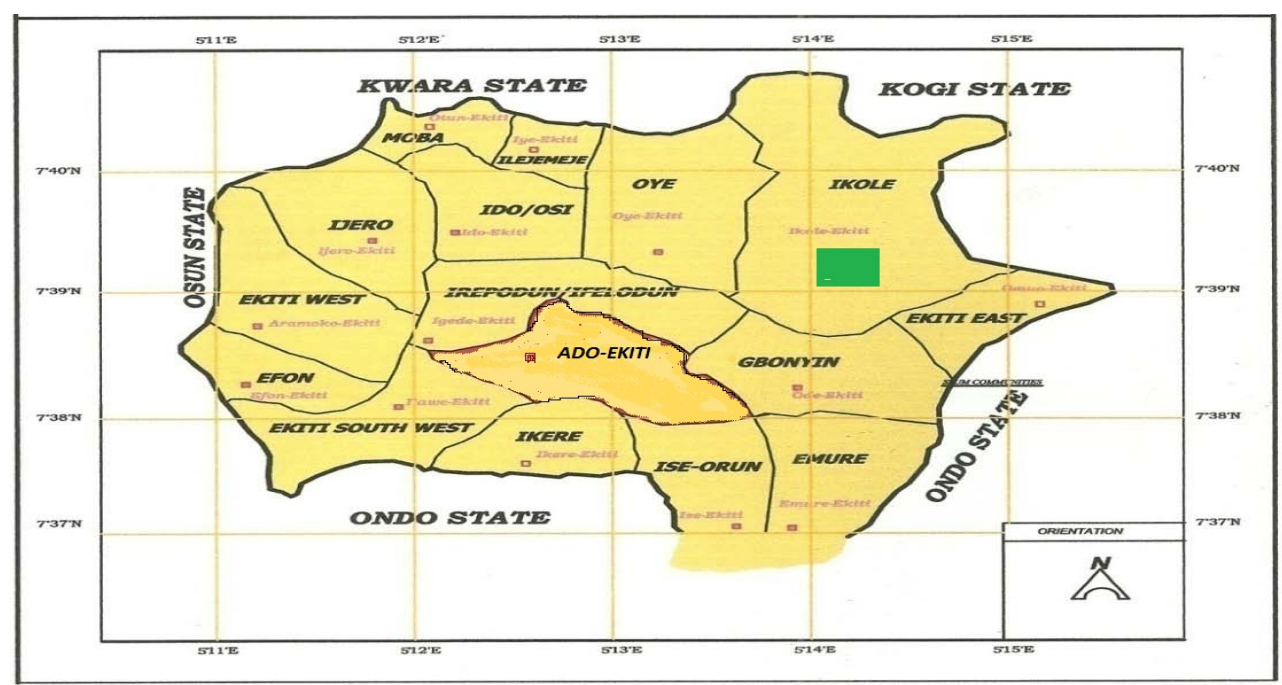

STUDY AREA

FIGURE 1: MAP OF EKITI STATE SHOWING THE STUDY AREA

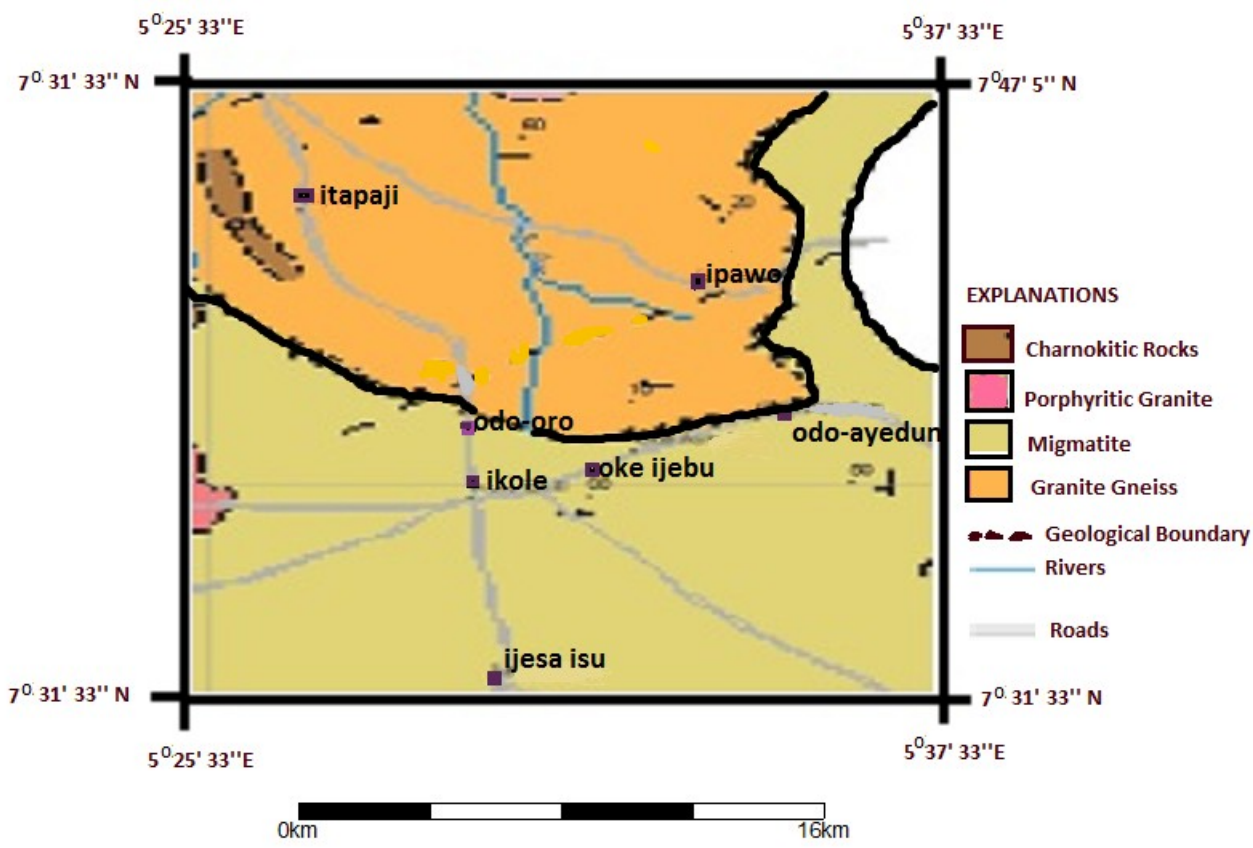

FIGURE 2: GEOLOGICAL MAP OF THE STUDY AREA (NGSA, 2006)

\section{Conclusion}

A study of the physiochemical and bacteriological properties of the water samples collected from the study area revealed that the water in the study area has no permanent chemically induced colour, they are tasteless, odourless and are slightly acidic. The low total dissolved solids (TDS) revealed the water to be from a fresh water source.

The determined chemical parameters reveal that the studied water samples have chemical qualities which render them suitable as drinking water as the determined parameters conforms to the [2] specifications for drinking water and also fell within the fresh water class of the USGS classification of water based on dissolved solids. 
The high bacteria count is beyond the limit of the World Health Organisation bacteriological standard for drinking water. This is unacceptable and not recommended as potable water unless special treatments and designs are adopted.

[1] Van Der Merwe C. R. (1962). Soil Groups and Sub-groups of South Africa. Div. of Chem. Services, Dept. of Agriculture, RSA.

[2] World Health Organization, (2007) International Drinking Water Standards. $3^{\text {rd }}$ Edition, Geneva.

[3] Asiwaju-Bello, Y.A and Akande, O.O. (2004): Urban groundwater pollution: Case study of a Disposal sites in Lagos

metropolis. Journal of Water Resources, 12: 22-26.

[4] Ige OO, Bale RB, Olasehinde PI (2008): Physio-chemical characteristics of water sources in Imeko, Southwestern, Nigeria. Water Res., 18: 32-36.

[5] Rahaman M.A and Malomo S. (1983): Sedimentary and crystalline rocks of Nigeria. In $\quad$ S.A. Ola Ed. Tropical Soils Of Nigeria In Engineering Practice. A.A Balkama Netherlands pp.17-38

[6] APHA (1998): Standard Methods for the Examination of Water and Wastewater $20^{\text {th }}$ Edition, American Public Health Association, Washington, DC USA, ISBN:0875532357; Pages 1270

[7] Ako, B. D. Adegoke, S. O., Ajayi, T. R., Ajayi,J. O. and Rahaman, M. A. 1986.Groundwater prospecting in Nigeria; Proc, Niwas. 1 st symposium Ikeja (Iwugo, K. O. Ed.). 3 - 44.

[8] Amadi, U. M. P., (1987): Mixing phenomenonin groundwater systems and its relevance in water quality and exploitation Nigeria. $2^{\text {nd }}$ Proc NIWAS, $17.1-17.31$.

[9] Hemm (1970): Study and Interpretation of the Chemical Characteristics of Natural Water. Water Supply Paper 2254, 3rd edition, US Geological Survey, Washington, D.C., 263 pp.

[10] Egboka, B. C. E., 1986. Hydrogeochemistry of shallow wells and surface waters of Owerri and its symposium, NIWASA, Pp. 305 - 328.

[11] Ezeigbo, H. H., 1988. Geological and Hydrogeological influences on the Nigerian Environment. Water Resources, Vol. 1, No. 1 Pp. $37-$ 44. 